\title{
RETHINKING THE EUROPEAN MODEL LAW OF SET-OFF IN THE ERA OF BREXIT AND THE RECENT REFORM OF THE FRENCH CIVIL CODE
}

\author{
Lidija Šimunović *
}

\begin{abstract}
In 2003 the Commission on European Contract Law (hereinafter: CECL) published the Principles of European Contract Law Part III (hereinafter: PECL III) which contained the provisions on EU set-off (hereinafter: EU model law of set-off). These are soft law provisions whose text was the result of the work of the most prominent academics from EU Member States. Considering that the Germanic, Romanic, and English set-off models coexist on the territory of the EU, the EU model law of set-off represents a reconciliation of the different private law traditions and models of set-off. During the 25 years since the adoption of the EU model law of set-off, several significant changes have occurred in the EU, which relate to its set-off law directly and indirectly. The most significant change is certainly the issue of Brexit and the possibility of Great Britain leaving the EU. Furthermore, it is important to note that automatic set-off was abandoned in France, which means it has replaced the Romanic set-off model with the German model.
\end{abstract}

This paper starts with the context in which the European set-off rules were adopted. Then, the author identifies the nomotechnical and practical deficiencies in the EU model law of set-off in the context of the changed circumstances in the EU. The final part of the paper presents propositions for the change of the existing EU model law of set-off, which would help overcome the identified deficiencies and gaps. Consideration is also given to the question of whether, after Brexit and the change in the French set-off rules, the provisions of the EU model law of set-off which were influenced by English and French set-off laws should be removed.

Keywords: set-off, EU set-off, PECL III, Brexit

\section{Introduction}

Set-off, as a means of discharging obligations, is not limited by state borders. Parties to set-off are mostly merchants from different states whose national set-off rules can differ significantly across the EU ter-

\footnotetext{
"Lidija Šimunović, PhD, Teaching Assistant, Faculty of Law, Josip Juraj Strossmayer University of Osijek, orcid.org/0000-0003-4753-5590. DOI: 10.3935/cyelp.15.2019.342.
} 
ritory. ${ }^{1}$ An additional issue can arise due to the fact that the national set-off rules of one party do not necessarily have to be known or available to the other party to set-off. For the above-mentioned reasons, the idea was born for the creation of set-off rules at the EU level which would be uniformly interpreted across the EU.

Legal experts who started advocating for the adoption of a European Civil Code which would be applicable across the EU in the $1980 \mathrm{~s}^{2}$ had the most significant role in the development of the EU model law of set-off. ${ }^{3}$ The Commission on European Contract Law (hereinafter: CECL) was established for that purpose. ${ }^{4}$ The first work as a product of the CECL was published in as early as 1995: Principles of European Contract Law Part $I^{5}$ This document prescribed the principles of European Contract Law, which were designed to be acceptable to all EU Member States. Thereupon, in 1999, the second part of PECL was published. ${ }^{6}$ Finally, the third part - PECL III - was published in 2003 and it contained the EU model law of set-off. ${ }^{7}$ The purpose of the adoption of this EU model law of set-off was the establishment of a common core of set-off rules 1 This paper was created as a result of research conducted at the Max Planck Institute for
Comparative and International Private Law in Hamburg, Germany, for which the author
received a one-month scholarship. In the paper, the term EU model law of set-off refers only
to the provisions of PECL III. The term Romanic model of set-off refers to the Italian, Spanish
and Greek national rules on set-off. The term Germanic model of set-off refers to the Ger-
man, Swiss and Austrian national rules on set-off. In this sense, see R Zimmermann, Com-
parative Foundations of a European Law of Set-off and Prescription (CUP 2002) 36. Wood
uses for Romanic model of set-off the term Napoleonic group, and for the Germanic model of
set-off, the term Roman-Germanic group of set-off. See PR Wood, Set-Off and Netting, Deriv-
atives, Clearing Systems (Sweet and Maxwell 2007) 10-11.

2 In this sense, see, for example: S Leible \& M Lehmann, European Contract Law and German Law (Kluwer Law International 2014) 630, 645-648, 693-696, 700-710; Zimmermann (n 1) 18-60. See also S Petrić, 'Introduction to the Principles of European Contract Law' (2008) 29(1) Journal of the Faculty of Law in Rijeka 1-10; S Petrić, 'The Draft Joint Referent Framework for European Private Law' (2009) 30(1) Journal of the University of Rijeka Faculty of Law 473; E Miščenić, 'European Contract Law on the Road From Soft Law to Hard Law: An Overview of the Optional Common European Sales Law (CESL)' (2012) 33(2) Journal of the University of Rijeka Faculty of Law 695; D Babić \& D Zgrabljić Rotar, 'The Reform of Conflict of Law Rules for Contractual Obligations in Law' (2010) Croatian Law Journal 54.

3 The term 'European law of set-off was introduced by Zimmermann (n 1) 18.

4 L Šimunović, 'Set-off (PhD thesis, Zagreb Faculty of Law 2019) 30.

5 Petrić, Principles of European Contract Law (n 2).

6 ibid.

7 ibid. The reason for the adoption of these rules was the national particularity of the regulation of the private law subject matter in the national legislature of the EU Member States, which was seen as an obstacle to the maintenance of a unique EU market. For more, see D Akšamović \& S Jelinić, 'UEU Contract Law at a Turning Point' (2010) 60(1) Journal of the Faculty of Law Zagreb 203. 
which would serve as a model for the adoption and interpretation of the law of the EU and the EU Member States. ${ }^{8}$

Today, 25 year later, it is time to assess the impact and importance of the EU model law of set-off. ${ }^{9}$ The EU model law of set-off was and still is the starting point for a broad range of doctrinal discussions because they represent a reconciliation of diverging private law traditions and set-off models.

Accordingly, this paper starts with the context in which the European set-off rules were adopted. Afterwards, the author provides an overview and analysis of the provisions of the EU model law of set-off. These provisions are analysed in the context of the changes which occurred on the EU market as well. The most significant change which is analysed refers to the issue of the sustainability of the applicable rules in circumstances where Great Britain is considering leaving the EU through Brexit. Furthermore, it is important to note that automatic set-off was abandoned in France, which means they have replaced the Romanic setoff model with the Germanic model. The final part of the paper aims to initiate future academic debate on the EU model law of set-off and gives future propositions for the EU model law of set-off, which would help overcome the identified deficiencies and gaps. The paper also asks whether, after Brexit and the change in the French set-off rules, the provisions of the EU model law of set-off which were influenced by English and French set-off laws should be removed.

\section{The period prior to the adoption of the EU model law of set-off}

An attempt to create unified rules of the law on obligations, ie a European Civil Code, was introduced back in 1982 by the Lando Commission $^{10}$ which consisted of esteemed legal experts and academics. ${ }^{11}$ In order to adopt the EU model law of set-off, the Lando Commission studied

\footnotetext{
8 This attempt to unify the EU model law of set-off through PECL III was not an isolated project. Later documents, such as the Draft Common Frame of Reference (hereinafter: DCFR) of 2017 also dealt with and regulated the issue of the EU model law of set-off. DCFR regulates set-off in its third book Obligations and Rights. This paper makes special reference to the set-off provisions from DCFR, because they are largely similar to the provisions of PECL III. Šimunović (n 4) 29-30.

9 For the purposes of this paper, the term set-off is not limited only to set-off as recognised by the national legislatures as a means of discharging mutual claims. Therefore, this paper does not address procedural or contractual set-off. Furthermore, the paper does not analyse the provisions which govern set-off in bankruptcy and execution proceedings, because these types of set-off are subject to the mandatory provisions of national set-off rules.

10 Commission on European Contract Law.

11 Šimunović (n 4) 28.
} 
the provisions of ten national laws of EU Member States on set-off. ${ }^{12}$ The three legal systems which stood out with distinguished models of set-off on the EU territory were Germany, England and France. In addition, other sources used in the adoption of PECL were the Uniform Commercial Code, Restatements of Law, the UNIDROIT Principles of International Commercial Contracts, and the Vienna Convention on Contracts for the International Sale of Goods (hereinafter: CISG). ${ }^{13}$

The starting point for the analysis of the national laws and the identified set-off models were the common features of all the national set-off rules of the EU Member States. ${ }^{14}$ In this sense, it was concluded that under all the reviewed systems, the terms 'set-off' and 'compensation' represent means of obligation discharge. It was also understood that there has been little systemic discussion on set-off in legal literature, that set-off is distinguished from set-off by agreement and compensable counter-claims, and that these are different legal terms. ${ }^{15}$

After establishing the preliminary conclusions, members of the Lando Commission narrowed their research only to the decision on the legal nature of set-off and the occurrence of its legal effects. The dilemma was whether set-off should be of a substantive or procedural nature, ie whether it should be automatic or unilateral and what impact this would have on the moment the effects of set-off occur. There were not many disagreements on these issues within the Commission, and thus the members easily agreed that set-off in the EU would be of a substantive and not of a procedural nature, and that it would occur at the moment of the unilateral notification of set-off (the so-called ex nunc effect) after the requirements for set-off were met, and not automatically by force of law, or from the moment the requirements for set-off were fulfilled. ${ }^{16}$

Despite the fact that consensus was easily reached, the discussions of the Lando Commission lasted for a longer time because the academics lingered on the doctrinal proof and on the confirmation of the thesis that the proposed solutions were correct and optimal. One of the most elaborated theses regarding the EU model law of set-off was the justification

\footnotetext{
12 Zimmerman states that a systematic analysis of Austrian, Dutch, English, French, German, Greek, Italian, Scottish, Spanish and Swedish law was undertaken for these purposes. Zimmermann (n 1) 18.

13 Šimunović (n 4) 29.

14 See Zimmermann (n 1) 1-17; Šimunović (n 4) 29. On the concept of set-off in comparative legal systems, see more in the chapter of Zimmermann (n 1) 19; P Pichonnaz \& L Gullifer, Set-off in Arbitration and Commercial Transactions (OUP 2014) 3.

15 Zimmermann (n 1) 18-22; Šimunović (n 4) 30.

16 Zimmermann (n 1) 56-60. More details on this will be provided in the following sections.
} 
of the ex nunc effect of the EU model law of set-off. ${ }^{17}$ This was due to the extensive scholarly debates which took place around the adoption of the Dutch Civil Code, which was enacted before PECL III and which adopted the retroactive model. ${ }^{18}$ At the time of the adoption of PECL III, the majority of countries at a comparative level (apart from the Nordic countries) had a retroactive effect of set-off. The creators of PECL did not follow the national solutions, nor those from the Dutch Civil Code, and they opted for the ex nunc effect of set-off.

The members of the Lando Commission justified their decision by stating that, contrary to the position held in the majority of national legislatures, retroactive effect was based on unjustified and unverified doctrinal determinations. ${ }^{19}$ The introduction of the ex nunc effect by the creators of PECL was justified by the fact that the effects of set-off do not have to be identical to the effects of payment or performance, and that the ex nunc effect leads to better results than the retroactive effect in the assessment of the effects of non-performance, interest and contractual penalties. ${ }^{20}$

All the work dedicated to the development of EU model law of set-off has resulted in the seven articles on EU set-off which were drafted by the CECL, and almost completely accepted in the final version of PECL III. ${ }^{21}$

\footnotetext{
17 N Jansen \& R Zimmermann (eds), Commentaries on European Contract Laws (OUP 2002) 1810.

18 ibid.

19 Zimmermann (n 1) 60.

20 ibid, 39.
}

21 See Šimunović (n 4) 31. O Lando \& H Beale, Principles of European Contract Law, Performance, Non-performance and Remedies (Martinus Nijhoff Publishers 1999) 95. For an easier understanding of the following analysis, the exact content of the EU model law of setoff is provided here: 'Article 13:101: Requirements for Set-off: If two parties owe each other obligations of the same kind, either party may set off that party's right to performance ("claim") against the other party's claim, if and to the extent that, at the time of set-off, the first party: (a) is entitled to effect performance; and (b) may demand the other party's performance. Article 13:102: Unascertained Claims: (1) A debtor may not set off a claim which is unascertained as to its existence or value unless the set-off will not prejudice the interests of the other party. (2) Where the claims of both parties arise from the same legal relationship it is presumed that the other party's interests will not be prejudiced. Article 13:103: Foreign Currency Set-Off: Where parties owe each other money in different currencies, each party may set off that party's claim against the other party's claim, unless the parties have agreed that the party declaring set-off is to pay exclusively in a specified currency. Article 13:104: Notice of SetOff: The right of set-off is exercised by notice to the other party. Article 13:105: Plurality of Claims and Obligations: (1) Where the party giving notice of set-off has two or more claims against the other party, the notice is effective only if it identifies the claim to which it relates. (2) Where the party giving notice of set-off has to perform two or more obligations towards the other party, the rules in Article 7:109 apply with appropriate adaptations. Article 13:106: Effect of Set-Off: Set-off discharges the obligations, as far as they are coextensive, as from the time of notice. Article 13:107: Exclusion of Right of Set-Off: Set-off cannot be effected: (a) where it is excluded by agreement; (b) against a claim to the extent that that claim is not 


\section{Present: the EU model law of set-off}

\subsection{Scope of application}

The text of PECL III itself states that the EU set-off provisions should be applied even without the parties' explicit consent in two instances. ${ }^{22}$ The EU model law of set-off is applicable if the parties agree that their contract is governed by general principles of contract law, lex mercatoria, or if they conclude a clause to a similar effect. ${ }^{23}$ The aforementioned provisions will be applied even if the parties do not agree to the law governing their contract and if it cannot be determined. ${ }^{24}$

In this sense, it could be concluded that the EU model law of set-off might be considered as model law and thus may represent a source of law in situations when contractual parties refer to them. In addition, the CJEU and the national courts might refer to the PECL in the context of contract interpretation or interpretation of contract law. This means that the EU model law of set-off will be applied even if the parties do not agree to the law governing their contract and if it cannot be determined.

\subsection{Requirements for set-off}

The EU model law of set-off does not provide a definition of set-off, but it opens with the circumstances under which obligations can be terminated through set-off. Article 13:101 PECL III provides that in the case where two parties owe each other obligations of the same kind, either party may set off that party's right to performance ('claim') against the other party's claim, if and to the extent that, at the time of set-off, the first party: (a) is entitled to effect performance; and (b) may demand the other party's performance. ${ }^{25}$

Therefore, it can be deduced that the requirements for set-off under the EU model law of set-off are the mutuality, the same kind and maturity of the obligation, while the obligation of the person seeking set-off does not have to be mature. Considering the fact that the above-mentioned requirements do not have the same meaning under different national laws, the following section analyses their meaning in the context of the EU model law of set-off.

capable of attachment; and (c) against a claim arising from a deliberate wrongful act.' $<$ www. trans-lex.org/400200/_/pecl/> accessed 12 June 2019.

22 See Article 1101 PECL III.

23 Šimunović (n 4) 30. Compare with Art 1101 para 3 PECL III.

24 Šimunović (n 4). In this sense, compare Art 1101 para 3.b PECL III, then, Leible \& Lehmann (n 2) 2-3 and Lando \& Beale (n 21) 95.

25 Article 13:101 PECL III. 


\subsubsection{Mutuality}

Mutuality is the first requirement for set-off under the EU model law of set-off. ${ }^{26}$ Under this requirement, both parties to set-off have to be the debtor and creditor of the other side simultaneously. ${ }^{27}$ These claims do not have to be of the same value or arise from the same legal basis. ${ }^{28}$ In order to establish mutuality as a requirement for set-off, the differences in the national legislatures of EU Member States have to be reconciled. ${ }^{29}$ Certain national legislation of Member States requires the claims to have the same legal basis, ie they have to be connected claims. ${ }^{30}$

If mutuality is observed in the context of the EU internal market, then the existence of mutuality as a requirement for set-off under the EU model law of set-off is a good solution, as it allows the efficiency and practicality of trade. Otherwise, if only claims arising out of the same legal basis or those of the same value could be set-off, the number of compensable claims would significantly decrease.

\subsubsection{Obligations of the same kind}

The second requirement for set-off under the EU model law of setoff is that the obligations have to be of the same kind. ${ }^{31}$ Claims are of the same kind if they both refer to money or another generic item of the same nature and quality. ${ }^{32}$ The existence of claims of the same kind is determined based on the moment when the set-off is raised. ${ }^{33}$ On a comparative level within the EU, there are divergent interpretations of this requirement. For example, under English law, only monetary

\footnotetext{
26 According to the provision of Article 13:101 PECL III.

27 Lat. concurs debiti et crediti. Zimmermann (n 1) 44-45.

28 Zimmermann (n 1) 45.

29 Cf § 387 German BGB; § 1438-144 Austrian ABGB; § 120 Swiss OR; Art 1291 French CC; Art 6:127 NGZ; Art 16.6 English Civil Procedure Rules of 1998; Art 1241-1243 Italian CC; Art 1196, 1197 and 1202 Spanish CC.

30 Zimmermann (n 1) 45; Wood (n 1) 509. For the set-off requirements in Croatian law, which is interpreted in the same way across the former Yugoslavia, see imunovi (n 4) 100102.

31 This requirement is not expressly defined, but its meaning can be derived from Article 13:101 PECL III.

32 Zimmermann (n 1) 48; O Lando, E Clive, A Prüm \& R Zimmermann (eds), Principles of European Contract Law, Part III (Kluwer Law International 2003) 140.

33 Zimmermann (n 1) 48. See also M Schuetler in W Krüger (ed), Münchener kommentar zum Bürgerlichen Gesetzbuch, band 2: Schuldrecht-Allgemeiner Teil (2nd edn, CH Beck 2016) 2651. For comparative law, compare § 387 BGB; § 1438 and § 1440 ABGB; § 120 OR; Art 1291 French CC; Art 6:127 para 2 English Civil Procedure Rules of 1998; Art 1196 Spanish CC; Art 1234 Italian CC. About the 'same kind' requirement from the perspective of comparative legal literature, see more in J Gernhuber, Die Erfüllung und ihre Surrogate sowie das Erlöschen der Schzldverhältnisse aus andren Gründen (Mohr Siebeck 1983) 67.
} 
claims can be set off, ${ }^{34}$ while under German or French law non-monetary claims can be set off as well, provided they are generic items of the same kind. ${ }^{35}$

The most important practical issue regarding claims of the same kind which the creators of the EU model law of set-off had to overcome was the set-off of monetary claims expressed in different currencies. ${ }^{36}$ This issue was regulated in Article 13:103 which provides that where parties owe each other money in different currencies, each party may set off that party's claim against the other party's claim, unless the parties have agreed that the party declaring set-off is to pay exclusively in a specified currency. ${ }^{37}$

Contrary to the EU model law of set-off, German law does not allow the set-off of monetary claims expressed in different currencies. ${ }^{38}$ Despite this, certain German authors are of the opinion that set-off should be allowed in such cases. ${ }^{39}$ Swiss and French literature is in line with such a modern understanding, which treats set-off claims expressed in different currencies as acceptable, as long as the currencies are mutually convertible, or there are other parameters which would allow their expression in the same currency. ${ }^{40}$

It thus arises that the needs of contemporary trade would be met by allowing the set-off of claims expressed in different currencies, as long as they are mutually convertible and there are no additional costs involved. ${ }^{41}$ The conversion rate for the calculation of the different monetary claims in set-off should be determined on the day of the notice of set-off because it is at this point that the legal effects of set-off come into force. ${ }^{42}$ The notice of set-off does not have any effects on the choice of currency for the conversion of the claims in set-off. Although this notice is a constitutive, unilateral legal act which is a precondition for set-off, the actual effects of set-off commence when the requirements for set-off are met. ${ }^{43}$

34 See also R Goode, Legal Problems of Credit and Security (3rd edn, Sweet \& Maxwell 2003) 153; Zimmermann (n 1) 48.

35 In that regard, see also for example § 387 BGB; Schuetler (33) 2651; Zimmermann (n 1) 48; § 120 OR; Art 1196 para 2 Italian CC; Art 1291 French CC.

36 Šimunović (n 4) 149-153.

37 See also Šimunović (n 4) 32-34.

38 Gernhuber (n 33) 220; Zimmermann (n 1) 49. Also imunovi (n 4) 151.

39 Also confirmed by Gernhuber (n 33) 220; Zimmermann (n 1) 49-50.

40 See also Šimunović (n 4) 151; PR Wood, English and International Set-Off (Sweet \& Maxwell 1989) 509; Zimmermann (n 1) 49.

41 Šimunović (n 4) 151.

42 See also ibid; Zimmermann (n 1) 10, 49; Schuetler (n 33) 26512652.

43 Šimunović (n 4) 150-151. 
Therefore, the currency should also be determined in accordance with the moment the claims are considered discharged. ${ }^{44}$

\subsubsection{Maturity}

Maturity is the third requirement of set-off under the EU rules. ${ }^{45}$ Just like the other requirements, it was not expressly defined, but was mentioned in the provision of 13:101 PECL III. The regulation of maturity as a requirement for set-off was done in accordance with German law. ${ }^{46}$ This solution is based on the understanding that the person who is declaring set-off is entitled to set off its mature obligation against the premature obligation of the other side, as soon as it has the right to offer the performance of its obligation. ${ }^{47}$ Maturity in set-off should be treated the same as in performance, and the set-off of obligations should be allowed before the maturity deadline. ${ }^{48}$

It is clear that the creators of the EU model law of set-off have regulated the maturity requirement in an appropriate manner. If an obligation can be performed before it is mature, then it should also be allowed to be set off under the same terms. The creditor of a premature claim who is expecting to set off his monetary claim once it is mature does not need protection if he is also a debtor who has defaulted on his obligation. ${ }^{49}$

The EU model law of set-off does not contain provisions to allow for the compensation of damages incurred by the person receiving a set-off notice. ${ }^{50}$ If damages are caused by set-off, the provisions for the compensation of damages for premature performance should be applied. ${ }^{51}$

The maturity requirement does not mean that a premature obligation can be set off against a mature obligation of the person declaring set-off. Such a solution would be contrary to the rules of performance under which the creditor cannot request performance of an obligation before it is mature. ${ }^{52}$

\footnotetext{
44 ibid.

45 See Article 13:101 PECL III. mann (n 1) 50.

47 W Johnston, Set-Off Law and Practice (OUP 2006) 175.

48 Šimunović (n 4) 150. For German law, see Gursky (n 46) 329.

49 See also Šimunović (n 4) 150 regarding the maturity requirement.

50 For German Law, see MüKoBGB/Schlüter, 2016, BGB § 391 R no 2.

51 Šimunović (n 4) 150.

52 imunovi (n 4) 154.
}

46 For German law, see KH Gursky, J. von Staudingers Kommentar zum Bürgerlichen Gesetzbuch mit Einführungsgesetz und Nebengesetzen, buch 2: Recht der Schuldverhältnisse §§362-396 (Erfüllung, Hinterlegung, Aufrechnung) (Sellier-de Gruyer 2016) 349; Zimmer- 
Therefore, a person cannot be put in a more favourable position through set-off than they would have been in if their obligation was terminated through performance..$^{53}$

\subsubsection{Actionability}

The EU model law of set-off allows for the set-off of claims whose performance cannot be forced. This arises out of Article 14:503 PECL III which provides that a claim can be set off after its expiration only if the debtor does not raise an objection immediately or within two months from the notice of set-off. ${ }^{54}$

This regulation is specific with regard to the provisions of the national laws of the Member States. For example, set-off is not allowed against claims which are objectionable. ${ }^{55}$ Unlike the German and EU regulation of the actionability requirement, Swiss law, through Article $\S 120$ paragraph 3 OR provides that a claim can be set off even after it has expired if it was valid at the moment when set-off became possible. ${ }^{56}$ Swiss authors state that only the claim of the person declaring set-off has to be actionable at the moment the legal requirements for set-off were fulfilled, while the compensated claim does not have to be actionable. ${ }^{57}$

The analysis of the compared laws and the EU model law of set-off leads to the conclusion that the various laws do not address the moment until which an expired claim can be set off. The solution provided in the EU model law of set-off is appropriate because it follows the logic that an expired claim still exists, but is no longer actionable. If the deadline for the objection was not provided, there would be great confusion due to the ability of the debtor to raise an objection for expiration of the claim at any time.

\footnotetext{
53 For German law, see also Gursky (n 46) 329.

54 See Article 14:503 PECL III. See also the DCFR and imunovi (n 4) 33.

55 This approach has been in force in Germany since 1 January 2002. Available at $<$ https:// vpn.pravo.hr/,DanaInfo=beck-online.beck.de,SSL+Dokument?vpath=bibdata\%5Cges\%5Cbgb\%5Ccont\%5Cbgb.p390.htm\&versionDate=20000101 \#lawversion $>$ accessed 4 December 2018. For German law, see K Larenz, Lehrbuch des Schuldrechts, erster band, Allgemeiner Teil (13th edn, CH Beck 1982) 258.

56 See Johnston (n 47) 435.

57 P Gauch, WR Schluep, J Schmidt, H Rey, \& S Emmenegger, Schweizeriches Obligationenrecht Allgemeiner Teil: ohne ausservertragliches Haftpflichtrecht, band 2 (10th edn, Schulthess 2014) 225-226.
} 


\subsubsection{Liquidity}

Article 13:102 PECL III provides that a debtor may not set off a claim whose existence or value is uncertain unless the set-off will not prejudice the interests of the other party. ${ }^{58}$ Where the claims of both parties arise from the same legal relationship, it is presumed that the other party's interests will not be prejudiced. ${ }^{59}$ This provision was introduced based on the influence of Romanic legal systems which also provide for the liquidity requirement. This requirement ensures that the claims in set-off cannot be contested in terms of their legal basis and amount. ${ }^{60}$

The analysis of the arguments in favour of and against the liquidity requirement shows that the existing provisions are not a good solution. Namely, the creators of PECL III have included the liquidity requirement, which is the approach taken by Romanic legal systems, where automatic set-off is the norm. In such cases, the obligations are terminated once the statutory requirements are met. However, PECL III accepts unilateral set-off, whose effects take place upon a unilateral notice of set-off, which is a unilateral legal act and which terminates the obligations regardless of the objections of the other party. Therefore, one of its main characteristics is the disregard of the reaction of the other party. On the other hand, the setting liquidity as a requirement for set-off (to a certain extent) seeks the reaction of the other party, who can contest the existence and amount of the claims and obligations in set-off, which raises the question of the intent behind this provision.

Under the EU model law of set-off, set off is a transformational right, the occurrence of which depends on the fulfilment of the requirements for set-off and the notice of set-off. Any objection raised from the other party would be contrary to the legal nature of set-off, which is a transformational right. According to the existing provisions, the introduction of liquidity as a requirement creates room for the objections of the other party. It also hinders the realisation of set-off. In other words, if the other party is dissatisfied with the fact that the claim was terminated through set-off, it can contest the claim itself and obstruct the set-off in general. Therefore, this requirement should be removed, and any doubts the parties might have about the legal basis and amount of claim should not have any impact on the legal effects of set-off. The legal effects of set-off will take place when the statutory requirements for set-off are fulfilled and the notice of set-off is made, and they should not depend on any

\footnotetext{
58 See article 13:102 (1) PECL III. See also HN Schelhaas, The Principles of European Contract Law (Part III) and Dutch Law: A Commentary II (Kluwer Law International 2006) 150.

59 Compare Article 13:102 paragraphs 1-2 PECL III with Article 6:103 DCFR. See also Šimunović (n 4) 32-34.

60 For Spanish law, see Article 1196 paragraph 4 of the Spanish CC.
} 
challenge made to a claim. The fact there is a dispute about some claim does not make it inadequate for set-off. ${ }^{61}$

Along with the aforementioned critiques, an additional issue caused by the liquidity requirement is the time limit for raising the liquidity objection. Considering the fact that the deadline was not expressly prescribed, the existing solution leads to legal uncertainty. Therefore, the time limit for the liquidity objection should be defined, just as in the case of actionability.

\subsection{Unilateral set-off}

Article 13:104 regulates the unilateral declaration of set-off by stating that the right of set-off is exercised by notice made to the other party. This shows that the creators of the EU model law of set-off chooses the Germanic set-off model, which is mainly represented by German law in which the obligations are terminated only after the notice of set-off which follows the fulfilment of the requirements for set-off. ${ }^{62}$

The EU model law of set-off has rejected the idea of automatic set-off which includes the notice of set-off as a prerequisite. Furthermore, it rejected the set-off model which is characteristic of English law and which requires a court decision which would allow the legal effects of set-off to take place.

A comparison of the automatic and unilateral set-off models shows that unilateral set-off is a better solution because of the improved information flow of the parties and it avoids unnecessary complications. This is also confirmed by the abandonment of automatic set-off in France and Italian practice where the notice of set-off is practised by default, although it is not a written rule, in order to avoid unwanted situations. ${ }^{63}$

\subsection{The legal effects of set-off}

Article 13:106 PECL III provides that set-off discharges the obligations, as far as they are coextensive, as from the time of the unilateral notice. This effect of set-off under EU rules is called the ex nunc effect (hereinafter: ex nunc effect or approach). ${ }^{64}$ Despite the fact that the EU

\footnotetext{
61 See also Šimunović (n 4) 165-166.

62 Unilateral set-off is present today in Austrian, Swiss, French and Croatian law. imunovi (n 4) 64.

63 Šimunović (n 4) 64-67.

64 ibid, 151. The Roman term ex nunc means: 'from now on - a term used in contract law to specify terms that are voided or confirmed in effect only in future and not only in the future and not prior to the contract, or its adjudication'. NH Nguyen, Essential 25000 English-Romanian Law Dictionary (e-book, no 8746, 2018).
} 
model law of set-off reflects the Germanic set-off model, it is specific for the fact that the legal effects under the EU model law of set-off does not have the retroactive effect that it has in the Germanic model of set-off. ${ }^{65}$

Therefore, the legal effects under the EU model law of set-off take place upon the unilateral notice of set-off but not retroactively from the moment when being suitable for set-off the obligations first confronted each other. ${ }^{66}$ The creators of the EU model law of set-off considered that it should induce the parties which have compensable claims to declare set-off as soon as possible. ${ }^{67}$

The possibility of retroactive set-off effects would allow the parties to delay and stall the discharge of compensable claims. ${ }^{68}$ They represent the viewpoint that the ex nunc approach to the effects of set-off is more equitable in terms of the calculation of interest and other ancillary rights. ${ }^{69}$ In their view, the retroactive effect of set-off deviates from the effects caused by the partial performance of claims, ${ }^{70}$ while the ex nunc effects are in line with these effects. ${ }^{71}$

The opponents of the ex nunc model state that the only purpose of set-off is the mutual discharge of opposing compensable claims, and not the inducement of any party to declare set-off. The persons subject to these rights should be allowed to make the most favourable choice, whether that is set-off or performance. ${ }^{72}$ It can be stated that the intent behind the adoption of the existing ex nunc effect model was to reconcile the differences among the opposing set-off effects. Despite this legitimate goal, this approach can be criticised from various angles. ${ }^{73}$

\footnotetext{
65 See Gursky (n 46) 421; P Pichonnaz, 'The Retroactive Effect of Set-Off (Compensatio): A Journey Through Roman Law to the New Dutch Civil Code' (2000) 68(4) Tijdschrift voor rechtsgeschiedenis 544. See also Šimunović (n 4) 212-214.

66 Zimmermann (n 1) 36.

67 R Zimmermann, Die Aufrechnung - Eine rechtsvergleichende Skizze zum Europäischen Vertragsrecht (Dieter Medicus 1999) 721-723.

68 Zimmermann (n 1) 39.

69 P Bydlinski, Die Aufrechung mit verjährten Forderungen: Wirklich kein Anderungsbedarf? (Archiv für die Civilistische Praxis, vol 196, 1996) 287; Zimmermann (n 1) 41.

70 Zimmermann (n 1) 39; P Gauch \& V Aepli, Obligationenrecht Das Erlöschen der Obligationen, 1 Lieferung, § 114-126 OR (3rd edn, Schulthess 1991) 65.

${ }^{71}$ See more in P Bydlinski, ,Die Aufrechung mit verjährten Forderungen: Wirklich kein Anderungsbedarf? (1996) Band 196, Heft 3, Archiv für die Civilistische Praxis 276; Zimmermann (n 1) 723; Zimmermann (n 1) 36-43. For the opposite opinion, see Gursky (n 46) 441. See also for Croatian law Šimunović (n 4) 212-214. B Mugdan, Die gesammten Materialien zum Bürgerlichen Gesetzbuch für das Deutsche Reich (band 1, R v Decker 1899) 512.

72 See also for Croatian law Šimunović (n 4) 212-214. Gursky opposes the ex nunc effects of set-off (n 46) 441.

73 See Gursky (n 46) 441. Zimmermann (n 1) 39.
} 
Firstly, the existing ex nunc effect of unilateral set-off under the EU model law of set-off is a very rare occurrence. ${ }^{74}$ Secondly, the criticisms of the opponents of the retroactive effect are truly not convincing. Namely, the purpose of the set-off rules is not the preferable treatment of set-off in comparison to performance as a means of discharging obligations. Both set-off and performance are equally valid ways to discharge obligations, and neither is superior or inferior to the other. ${ }^{75}$ Therefore, the opponents of the ex nunc effects of set-off are right to conclude that the intent of the legislator cannot be the inducement of set-off notices by parties, because such a decision is left to the disposal of the parties. ${ }^{76}$

The third and most important criticism is the fact that the retroactive effects of set-off match the effects of real performance. In particular, the different treatment of retroactive effects and performance which is invoked by the proponents of the ex nunc approach are not caused by the retroactive effect, but rather by the inaccurate calculation of the main and ancillary claims. If the calculation of the main and ancillary claims is done carefully, then the effects of the retroactive approach to set-off and performance are completely harmonised. ${ }^{77}$

Contrary to this, in the ex nunc approach there is a different treatment in comparison to the effects of performance, because it discards ancillary claims of the side whose claim became due before the counterclaim. Therefore, the recommendation is that the EU set-off moves from ex nunc to retroactive effects in order to harmonise the effects of set-off with the effects of performance.

\subsection{Calculations in set-off}

Article 13:105 PECL III provides that where the party giving notice of set-off has two or more claims against the other party, the notice is effective only if it identifies the claim to which it relates. ${ }^{78}$ Where the party giving notice of set-off has to perform two or more obligations towards the other party, the rules in Article 7:109 apply with appropriate adaptations. ${ }^{79}$

74 N Jansen \& R Zimmermann 2002, Commentaries on European Contract Laws (OUP 2018) 1810.

75 Set-off and performance are not in a mutual position of superiority or inferiority. Šimunović (n 4) 214.

76 Gursky (n 46) 441. For Croatian law, see Šimunović (n 4) 214.

77 In this sense, see Šimunović (n 4) 214; Gursky (n 46) 441.

78 Article 13:104 (1) PECL III. In this sense, compare the rules on the calculation of performances for multiple claims: Article 13:105 paragraph 2 with Article 9:109 paragraph 3 PECL III and Article 6:106 DCFR with Article 7:109 paragraph 3.

79 Article 13:104 (2) PECL III. 
This means that the party giving notice of set-off may determine which of these claims are to be set off against each other. If there is no such specification given, the general rule relating to the appropriation of performance will apply mutatis mutandis. ${ }^{80}$ Although it is not expressly provided, the set-off of claims with different locations of performance is allowed. ${ }^{81}$

This framework follows the same logic which flows from the provisions on multiple performances, and it also follows the solutions from other comparable legislatures. There was no need to duplicate the provisions on calculations for set-off, since they already exist for the performance which is being replaced by set-off.

\section{The existing EU model law of set-off in the era of Brexit and the changes in the French set-off rules}

The EU model law of set-off was created at a time when there were three main set-off models in the EU: German law as the main representative of unilateral set-off (the so-called Germanic set-off model), French law as the main representative of automatic set-off (the Romanic set-off model) and English law as the main representative of procedural set-off (the English law set-off model). ${ }^{82}$

In an era when it is only a matter of time before Britain leaves the $\mathrm{EU}$, and after the changes in the French Law on Obligations regarding the set-off rules in 2016, when French law abandoned automatic for unilateral set-off (ie abandoned the Romanic for the Germanic model), ${ }^{83}$ it is fitting to address the sustainability of the EU model law of set-off in its current form. This issue is relevant because the EU model law of set-off contains elements of both English and French law.

Firstly, it is evident that English law has had a great influence on the EU model law of set-off, since the English model has ex nunc and not retroactive effects. ${ }^{84}$ Therefore, after Brexit, Britain will no longer be the

\footnotetext{
80 Zimmermann (n 1) 60.

81 ibid.

82 This division was introduced by Zimmermann (n 1) 36.

83 For more on the reform of the French Law on Obligations, see N Dissaux, Réforme du droit des contrats, du régime général et de la preuve des obligations: (ordonnance no 2016131 du 10 février 2016): commentaire des articles 1100 à 1386-1 du code civil (Dalloz, DL 2016) 219.

84 For set-off rules under English law which used to be an inspiration for the EU model law of set-off, see the Insolvent Debtors Relief Act of 1729 (confirmed and amended by the Debtors Relief Amendment Act of 1735) the so-called Statutes of Set-Off. See also the Supreme Court of Judicature Act of 1873 for procedural rules regarding set-off in English law (Zimmermann (n 1) 26-28). Today many types of set-off exist in English law, such as statute
} 
biggest proponent of the highly criticised ex nunc approach of the EU model law of set-off. Despite this, even if Britain leaves the EU it is indisputable that EU Member States, such as Ireland or Malta as common law jurisdiction countries, will retain national rules which have ex nunc effects of set-off, ${ }^{85}$ ie rules which are the same or very similar to the English rules on set-off. ${ }^{86}$ Therefore, Brexit itself will not lead to the need to abandon the ex nunc effects of the EU Model law of set-off, because there will be other legislatures which have adopted this model. Even if there were no national legislatures within the EU adopting the ex nunc effect of set-off, this would not mean that such an effect should be eliminated from the EU model law of set-off if this is a good solution. However, if the arguments and results of comparative analysis are taken into account, the ex nunc effect of the EU model law of set-off is not a good solution. According to the author's best knowledge today, with a sufficient lapse of time, the ex nunc effect of set-off has not only failed to yield the results promised by its creators, but the arguments its creators provided for its introduction are contrary to the very legal nature of the EU model law of set-off. 87

On the other hand, retroactivity is primarily in accordance with the legal nature of set-off and it contributes to legal security. Set-off is a surrogate for performance. Therefore, the logic behind the legal effects of set-off should follow the solutions which exist for performance. Treating set-off as a surrogate for performance does not make it inferior or superior to performance as a modality of the discharge of obligations, but it means that they have that they are of an equal status. Therefore, the parties to set-off choose whether to discharge their obligations through performance or set-off. ${ }^{88}$ This is why retroactivity is better because the parties know when the effects of set-off will take place and it matches the effect of performance. Therefore, there is no need to leave the decision on

set-off, contractual set-off and insolvency set-off (W Johnston \& T Werlen, Set-Off Law and Practice (OUP 135); PR Wood, English and International Set-off (Sweet and Maxwell 1989) 23-24; SR Derham, Set-off (OUP 2010) 6; SI Sepinuck, 'The Problems of Set-Off: A Proposed Legislative Solutions' (1988) 3 William \& Mary Law Review 55). According to Derham, there is also a similar legal institute of a banker's right of set-off (Derham) 6. For case law on set-off under English law, see Rawson $v$ Samuel (1848) CR and TH 161, 41; Hanak $v$ Green (1958) 2 QB 9; Bankes $v$ Jarvis (1903) 1 KB 549; Federal Commerce \& Navigation Co Ltd $v$ Molena Alpha Inc (1978) 2 QB 927; Bank of Boston Connecticut $v$ European Grain and Sugar Ltd (1989) AC 1056; Dole Dried Fruit and Nut Co v Trustin Kerwood Ltd (1990) 2 Lloyd's Rep 309; Bin Kemi v Blackburn Chemicals Limited (2001) 2 Lloyd's Rep 93; and Esso Petroleum Co Ltd v Milton (1997) 1 WLR 938, 953.

85 Wood (40) 9.

86 Ibid. See also N Jansen \& R Zimmermann, Commentaries on European Contract Laws (OUP 2018) 1810.

87 Zimmermann (n 1) 38.

88 Šimunović (n 4) 48. 
when the effects of set-off will take place to the party notifying set-off, which is the case with the ex nunc effect.

In light of the above, it can be concluded that Brexit itself does not induce the need to abandon the ex nunc effect of set-off, but it enunciates the identified flaws of the ex nunc effect of set-off. Thus, the recommendation is that the text of the EU model law of set-off regarding the effects of set-off (Article 13:106 PECL III) should be amended to read the following: 'The effect of set-off is that the claims, to the extent that they correspond, are deemed to expire at the time they are set against each other as being appropriate for set-off', ${ }^{89}$

Aside from Brexit, another significant change happened in the French Law on Obligations in relation to set-off. The changes in the French law did not have any influence on the EU model law of set-off because the amendments to the French law occurred in 2016, after the adoption of PECL III. However, it is unlikely to influence the EU model law of set-off in the future either, because the abandonment of automatic for unilateral (Germanic) set-off confirms that the Germanic model is preferable. Namely, French authors state that the amendments in the French law were made because the Germanic model is more practical and provides more information for the parties. ${ }^{90}$

The Germanic set-off model which was adopted by the EU model law of set-off is more practical because the decision on whether to set off obligations at all is left to the will of the parties, and not the mere fact that the requirements for set-off were met. ${ }^{91}$ Therefore, under the Germanic model, the parties can decide not to set off but to perform their obligations, which is not possible with automatic set-off. The main disadvantage of automatic set-off is the legal uncertainty which arises when one party has several claims while the other has only one. In such situations, it is difficult to determine which exact claim is discharged because there is no notification of set-off which would expressly provide this information. ${ }^{92}$ This is confirmed by the practice under Italian law which adopts the Romanic model of set-off, where the parties provide notice of set-off to ensure that the other side is fully aware, which provides some legal security. ${ }^{93}$

\footnotetext{
89 As in paragraph 389 BGB.

90 P Pichonnaz, Set-Off Compensatio: From Diversity Unit Comments on the Principles of European Contract Law, (Universitat de Lleida Tirant lo Blanch 2005) 287.

91 ibid; Šimunović (n 4) 66.

92 ibid.

93 MN Kannengiesser, Die Aufrechnung im internationalen Privat- und Verfahrensrecht: Mit vergleichender Darstellung ausgewählter europäischer Aufrechnungsrechte (Mohr Siebeck 1998) 7.
} 
Parties which are better informed are not only aware of the occurrence of set-off, but they are also in a better position to calculate the ancillary claims, such as interest and contractual penalties, as well as to prove the actual existence of the claims. Finally, in a certain way, it could be concluded that the adoption of the EU set-off rules inspired the French legislators to amend the French Code civil with regard to set-off. In the upcoming period, it will be interesting to observe whether Spain and Italy will follow the French lead and abandon the Romanic for the Germanic set-off model. ${ }^{94}$

\section{Instead of a conclusion: the future of the EU model law of set-off}

The EU model law of set-off has had a great impact on European private law, because its adoption opened a number of important legal questions and initiated the first systematic comparative analysis of national set-off provisions at the EU level. EU set-off is unilateral and not automatic, but the effects of set-off take place after the notice of set-off is given to the other side (the so-called ex nunc effects), and not as soon as the legal requirements are met. ${ }^{95}$

This approach was introduced under the strong influence of Great Britain and it differs greatly from the Germanic approach and it is rightly criticised. It deviates from the regular regime which applies for the performance of obligations and it unduly disregards the ancillary rights (interest and costs) of only one party. The party whose claim is mature will thereby have the advantage, because the set-off effects take place later than they would under the retroactive approach. Thereby, the party whose claim matures at a later stage will not have to pay the interest it usually would if set-off had not occurred.

Therefore, retroactivity is a better solution than the ex nunc effect because it comports with the legal nature of set-off and it contributes to the legal certainty of the parties in set-off. The retroactive effects of set-off match the effects of performance and the parties in set-off know when these legal effects will take place. Thus, there is no need to allow the notifying party to determine when the effects of set-off will take place, which is allowed with the ex nunc effect.

The disadvantages of retroactivity which were cited by the creators of the EU model law of set-off are not accurate because if the calculation rules are applied carefully through the retroactive set-off approach, then its effects will match those of partial performance. Therefore, consider-

\footnotetext{
94 ibid.

95 Šimunović (n 4) 33.
} 
ing the results of the conducted analysis, there should be a shift from the existing ex nunc approach (from the moment of the unilateral notification of set-off) to the retroactive effects of set-off (from the moment the requirements of set-off were fulfilled for the first time).

With regard to Brexit, there is no doubt that the most prominent proponent of the ex nunc effects of set-off will leave the EU, but other countries adopting the same approach will remain (such as Ireland and Malta). However, although Brexit itself does not lead to the elimination of the ex nunc effect of set-off, it brings its deficiencies to the surface.

In the context of the changes in French law regarding set-off, it is concluded that they do not have any effect on the EU model law of set-off. On the contrary, the changes which have occurred in French law with regard to set-off prove that the unilateral set-off model which is adopted in the EU model law of set-off is a good solution because parties who are better informed are not only aware of the occurrence of set-off, but they are also in a better position to calculate the ancillary claims such as interest and contractual penalties, and to prove the actual existence of the claim. However, it will be interesting to see how this will impact on other legal systems, such as Italy and Spain, which still adopt the automatic set-off model.

\section{(c) $(1) \Theta \Theta$}

This work is licensed under the Creative Commons Attribution - Non-Commercial - No Derivatives 4.0 International License.

Suggested citation: L Šimunović, 'Rethinking the European Model Law of SetOff in the Era of Brexit and the Recent Reform of the French Civil Code' (2019) 15 CYELP 135 